\title{
Neospora caninum antibodies in dairy cattle of Lages Municipality, Santa Catarina State, Brazil
}

\author{
Anticuerpos séricos contra Neospora caninum en rebaños lecheros de la ciudad de Lages, \\ Estado de Santa Catarina, Brasil \\ AB Moura*, AP Souza, AA Sartor, V Bellato, EB Teixeira \\ Departamento de Medicina Veterinária, Centro de Ciências Agroveterinárias, Universidade do Estado de Santa Catarina, Brasil.
}

\begin{abstract}
RESUMEN
Los bovinos son los principales hospederos intermediarios del coccidio Neospora caninum. En esta especie se concentran la mayoría de los daños reproductivos. A fin de determinar la prevalencia de $N$. caninum e identificar factores de riesgo para la infección en el ganado lechero de la ciudad de Lages, Estado de Santa Catarina, se tomaron muestras de sangre de bovinos $(\mathrm{n}=373)$ y los perros $(\mathrm{n}=33)$ en 19 propiedades. La detección de anticuerpos contra N. caninum fue realizada por medio de IFA. Fueron consideradas positivas las muestras con títulos $\geq 200$ (ganado bovino) y $\geq 50$ (perros). Informaciones relacionadas con la categoría de los animales, la raza, la frecuencia y tipo de trastornos de la reproducción, la producción de leche y la presencia de los perros fueron obtenidos mediante un cuestionario. Los datos fueron analizados con la prueba exacta de Fisher y $\chi^{2}(\mathrm{P} \leq 0,05)$. De las muestras de ganado y canino evaluados, $86(23,1 \%)$ y $7(21,2 \%)$ fueron positivas a $N$. caninum, respectivamente. Se encontró correlación entre los animales con baja producción y la seropositividad a $N$. caninum $(\mathrm{P}=0,003)$. La presencia de perros positivos en las propiedades no representa un factor de riesgo de positividad en el ganado vacuno. No se observó una asociación estadísticamente significativa entre trastornos reproductivos con la aparición de anticuerpos contra $N$. caninum en bovinos evaluados. Los resultados obtenidos indican que $N$. caninum está presente en el ganado lechero de la ciudad de Lages, Santa Catarina.
\end{abstract}

Key words: Neospora caninum, dairy cattle, risk factors, Santa Catarina State.

Palabras clave: Neospora caninum, bovinos lecheros, factores de riesgo, Santa Catarina.

\section{INTRODUCTION}

Bovine are the main intermediate host of Neospora caninum, a coccidian protozoan. This protozoan parasite is a major cause of bovine abortions and neonatal mortality worldwide (Thilsted and Dubey 1989). Infection occurs following ingestion of sporulated oocysts or introduction by the transplacental route (Dubey and Lindsay 1996). Calves congenitally infected can develop the clinical disease or maintain the infection in the herd through vertical transmission, which is the main route of transmission of N. caninum in dairy cattle (Davison et al $1999^{\mathrm{a}}$ ).

Research has demonstrated that neosporosis is the major cause of abortions in bovine (Sadrebazzaz et al 2007), with abortions being a common clinical sign of infection. Nevertheless, in some countries or regions, other causes of abortion (infectious or not) may be more important than $N$. caninum infection. Flausino et al (2006) observed a strong association among abortions and seropositivity for $N$. caninum in dairy herds in Rio de Janeiro State. Recurrent abortions in the same cow are an indication of possible $N$. caninum infection (Locatelli-Dittrich et al 2004). Aborted fetuses and calves congenitally infected can present viable

Accepted: 05.04.2012.

* Av. Luís de Camões, 2090, Lages, SC, Brazil; a2abm@cav.udesc.br cysts of the parasite in their tissues, and become a source of infection for definitive hosts such as dogs, that may feed on infected carcasses. In addition to reproductive disorders, $N$. caninum is implicated as a factor in reduced milk production (Thurmond and Hietala 1997, Hernandez et al 2001, Hobson et al 2002) and lower concentrations of fat and protein in milk (Tiwari et al 2007). Cruz et al (2011) demonstrated the importance of neosporosis on health herd in dairy cattle.

There is no evidence that $N$. caninum infects humans, however, the prevalence of antibodies against this agent in humans has been reported (Almeida 2004, Lobato et al 2006). Experimental inoculations in primates demonstrated congenital transmission of the protozoa and showed that clinical neosporosis in primates was similar to congenital toxoplasmosis in humans (Baar et al 1994).

In Brazil, the prevalence of antibodies against $N$. caninum in cattle ranges from $6.8 \%$ to $67.8 \%$ in the different regions of the country (Gennari 2004). Melo et al (2001) analyzed the frequency of $N$. caninum infection in 18 dairy herds in the state of Minas Gerais and reported a cattle seroprevalence ranging from $0 \%$ to $72.73 \%$. Table 1 displays the importance and the presence of $N$. caninum infection in bovine of several regions of Brazil. Although an outbreak of abortions due to $N$. caninum was confirmed in the Santa Catarina State (Corbellini et al 2001), no epidemiologic studies were done to establish the 
Table 1. Prevalence of antibodies against Neospora caninum in bovine in Brazil, technique employed and reference.

Prevalencia de anticuerpos contra Neospora caninum en bovinos en Brasil, técnica empleada y referencia.

\begin{tabular}{|c|c|c|c|c|}
\hline Reference & County & Samples evaluated & Occurrence $(\%)$ & $\begin{array}{l}\text { Technique } \\
\text { (Cut off) }\end{array}$ \\
\hline Hasegawa et al (2004) & $\mathrm{SP}$ & 777 & 15.57 & IFAT $(1: 200)$ \\
\hline Locatelli-Dittrich et al (2004) & PR & 172 & 34.8 & ** \\
\hline Ogawa et al (2005) & PR & 385 & 12 & IFAT $(1: 200)$ \\
\hline Rodrigues and Cury (2005) & MG & 245 & 4.48 & IFAT internet \\
\hline Vogel et al (2006) & RS & 798 & 11.4 & ELISA $(* *)$ \\
\hline \multirow[t]{2}{*}{ Munhoz et al (2006) } & $\mathrm{RJ} *$ & 303 & 25.7 & ELISA $(* *)$ \\
\hline & $\mathrm{RJ}^{*}$ & 260 & 20.4 & ELISA $(* *)$ \\
\hline \multirow[t]{2}{*}{ Mineo et al (2006) } & MG* & 174 & 20 & ELISA $(1: 100)$ \\
\hline & MG* & 69 & 10 & ELISA $(1: 100)$ \\
\hline Melo et al (2006) & GO & 930 & 30.4 & IFAT (1:250) \\
\hline Guimarães et al (2006) & MG & 362 & 90 & IFAT $(1: 200)$ \\
\hline Juliano et al (2006) & GO and TO & 468 & 38.24 & $\operatorname{ELISA}(* *)$ \\
\hline Oshiro et al (2007) & MS & 2,448 & 14.9 & IFAT (1:50) \\
\hline \multirow[t]{2}{*}{ Guedes et al (2008) } & MG* & 559 & 91.2 & IFAT $(1: 200)$ \\
\hline & MG* & 575 & 97.2 & IFAT $(1: 200)$ \\
\hline Locatelli-Dittrich et al (2008) & PR & 1,263 & 33 & $\operatorname{ELISA}(* *)$ \\
\hline Minervino et al (2008) & PA & 160 & 19 & IFAT $(1: 100)$ \\
\hline Mello et al (2008) & MS & 392 & 9.17 & IFAT (1:50) \\
\hline
\end{tabular}

ELISA = Enzyme-linked immunosorbent assay.

IFAT = Indirect immunofluorescent antibody test (Técnica de inmunofluorescencia indirecta).

* Municipality or herds distinct.

** Not Described.

* Ciudades o rebaños separadas.

** No se describe.

seroprevalence of $N$. caninum. This study was designed to examine seroprevalence of $N$. caninum in dairy cattle of Lages municipality, Santa Catarina State and risk factors for neosporosis infection.

\section{MATERIAL AND METHODS}

Between August 2007 and February 2008, blood was collected from 373 bovines on 19 dairy farms in Lages Municipality, situated in the mountain region of the Santa Catarina State, southern Brazil (2748'57'S, 5020'33”'W) at an altitude of $916 \mathrm{~m}$, with a mean annual temperature of $14.3^{\circ} \mathrm{C}$. The size sample considered a prevalence of $20 \%$, error of $2.5 \%$ and a confidence level of $95 \%$ (EPI-INFO 6.0). Blood samples were randomly collected from calves, heifers, lactating cows, dry cows and bulls. Nearly $84 \%$ of the animals were lactating cows randomly selected among the adult female cattle. The occurrence of abortions was not used as a criterion to select the farms or the animals. Sera were obtained by centrifugation and kept at $-20^{\circ} \mathrm{C}$ until assayed.

An indirect immunofluorescent antibody test (IFAT) was performed according to Conrad et al (1993) using tachyzoites of the NC1 strain of $N$. caninum (Dubey et al $1988^{\mathrm{b}}$ ), and a commercial fluorescein-labeled whole rabbit anti-bovine IgG (Sigma-Aldrich Co.) was used as the secondary antibody. Complete tachyzoite peripheral fluorescence (Paré et al 1995) at a dilution of 1:200 was considered positive for $N$. caninum antibodies in cattle (Dubey and Lindsay 1996). Negative and positive control sera were used on each slide. Positive sera were diluted two-fold up to the maximum titer.

Additional blood samples were gathered from dogs $(\mathrm{n}=33)$ that coexisted with bovine on the evaluated properties. Dog blood was analyzed for $N$. caninum antibodies using the IFAT method (cut-off $\geq 50$, Silva et al 2007).

Herd data (breed, management, frequency and type of reproductive or neurologic disorders in the last 12 months, production of milk, diet and presence of dogs) was obtained from the owners.

\section{STATISTICAL ANALYSIS}

The data were tabulated and analyzed statistically by using Fisher's exact ${ }^{1}$ and qui-square tests $(\mathrm{P} \leq 0.05)$ to correlate the results of serology with potencial risk factors.

R Development Core Team. 2009. R: A language and environment for statistical computing R Foundation for Statistical Computing, Vienna, Austria ISBN 3-900051-07-0, URL http://wwwR-projectorg. 


\section{RESULTS}

Neospora caninum antibodies were found in $23.1 \%$ ( 86 positive/373 tested) of cattle and $21.2 \%$ (7/33) of dogs. The titers detected in bovine serum samples were 1:200 (18), 1:400 (23), 1:800 (29), 1:1600 (14) and 1:3200 (2). Serological evidence of neosporosis was found on all farms included in the study (table 2), suggesting widespread occurrence of the protozoan among dairies of Lages, Santa Catarina.

Infection was primarily found in animals with low milk production $(\mathrm{P}=0.008)$. More than half $(55.6 \%)$ of the cows with low production ( $<10$ liters of milk per day) were $N$. caninum seropositive (table 3 ).

\section{DISCUSSION}

In the present study, $N$. caninum seropositivity was similar to the $19 \%$ prevalence reported by Minervino et al (2008) in Santarém, Pará State, 23.6\% described by Ragozo et al (2003) and 26\% related by Romero-Salas et al (2010). Alternatively, Ogawa et al (2005), Vogel et al (2006), Corbellini et al (2006) and Oshiro et al (2007) reported lower seropositive values of $12 \%, 11.4 \%, 17.8 \%$ and $14.9 \%$, respectively. In contrast, Boaventura et al (2006), Guimarães et al (2006), Locatelli-Dittrich et al (2008) and Benetti et al (2009), found 40.7\%, 90\%, 33\% and $53.5 \%$ of positive animals had antibodies against $N$. caninum. Ragozo et al (2003) and Guimarães Junior et al (2004) both reported the highest rates of seropositivity were from older cows. A similar predominance was observed in this study, were $84 \%$ of positive are lactating cows, but the difference was not significant (table 3). Horizontal transmission within dairies endemically infected normally shows a predominance of infection in older cattle (Davison et al 1999a). Therefore, the results suggested infection in the herds in this study occurred by horizontal transmission, which has been reported by others (Davison et al 1999a, Dyer et al 2000).

The low productivity cows, with bigger seropositive rates, were from two farms with less technological systems, suggesting management practices could have contributed to a higher prevalence of $N$. caninum antibodies in these herds. The same was observed by Corbellini et al (2006) and Wang et al (2010)

The prevalence of neosporosis in bovines is higher in aborting cows when compared to normally calving cattle (Davison et al 1999 ${ }^{\mathrm{b}}$, De Meerschman et al 2002, Ghalmi et al 2007, Almería et al 2009), although Oshiro et al (2007) found a positive correlation between low titers of bovine $N$. caninum antibodies and abortions. In this study, no significant association was observed between the prevalence of antibodies against $N$. caninum and reproductive disorders in bovine, in agreement with findings of Aguiar et al (2006). Similarly, Paz et al (2007) found no association between $N$. caninum seropositivity
Table 2. Positive dairy cattle (IFAT, $\geq 1: 200$ ) for Neospora caninum, per farm, from the municipality of Lages, Santa Catarina State, for analyzed variable and total. 2008.

Ganado lechero positivo (IFAT $\geq 1: 200$ ) por Neospora caninum, por granja, del municipio de Lages, Estado de Santa Catarina, para variables analizadas y total. 2008.

\begin{tabular}{lccc}
\hline Farm & $\begin{array}{c}\text { Bovines } \\
\text { Evaluated }\end{array}$ & \multicolumn{2}{c}{$\begin{array}{c}\text { Bovines } \\
\text { Positive }(\%)\end{array}$} \\
\hline 01 & 19 & 03 & $(15.8)$ \\
02 & 19 & 03 & $(15.8)$ \\
03 & 33 & 07 & $(21.2)$ \\
04 & 37 & 07 & $(18.9)$ \\
05 & 24 & 04 & $(16.7)$ \\
06 & 12 & 01 & $(8.3)$ \\
07 & 24 & 05 & $(20.8)$ \\
08 & 15 & 05 & $(33.3)$ \\
09 & 35 & 15 & $(42.9)$ \\
10 & 25 & 05 & $(20)$ \\
11 & 13 & 09 & $(69.2)$ \\
12 & 13 & 04 & $(30.8)$ \\
13 & 26 & 02 & $(7.7)$ \\
14 & 18 & 02 & $(11.1)$ \\
15 & 05 & 01 & $(20)$ \\
16 & 06 & 03 & $(50)$ \\
17 & 16 & 05 & $(31.3)$ \\
18 & 12 & 01 & $(8.3)$ \\
19 & 21 & 04 & $(19.1)$ \\
\hline Total & 373 & 86 & $(23.1)$ \\
\hline & & &
\end{tabular}

and pregnancy rates in cows belonging to a surrogate herd submitted to embryo transfer technology.

Although Basso et al (2010) observed the horizontal infection route determines the occurrence of epidemic abortions, the abortion rate was not increased in a dairy herd infected by horizontal transmission (Dijkstra et al 2002), which suggested the existence of low virulent strains of the protozoan, such as observed for T. gondii. The identification and characterization of $N$. caninum strains of low virulence could explain the lack of an association between seroprevalence for neosporosis and reproductive disorders in the dairies included in the present study (Dubey et al 2006, Rojo-Montejo et al 2009a , Rojo-Montejo et al 2009 ${ }^{\mathrm{b}}$ ).

At least one dog positive for neosporosis was detected in six (31.6\%) of 19 evaluated dairies. However, we found no correlation between $N$. caninum seroprevalence in cattle and the presence of infected dogs. Similarly, Aguiar et al (2006), Locatelli-Dittrich et al (2008) and Mello et al (2008) did not observe any correlation between presence of dogs and seropositivity for $N$. caninum in cows. In contrast, Guimarães Junior et al (2004) reported a positive correlation between the presence of dogs and the prevalence 
Table 3. Frequency of positive dairy cattle (IFAT, $\geq 1: 200$ ) for Neospora caninum from the municipality of Lages, Santa Catarina State, for analyzed variable and total. 2008.

Frecuencia de ganado lechero positivo (IFAT $\geq 1: 200$ ) por Neospora caninum del municipio de Lages, Estado de Santa Catarina, para variables analizadas y total. 2008.

\begin{tabular}{|c|c|c|c|c|c|c|c|c|}
\hline \multirow{2}{*}{ Variable } & \multirow{2}{*}{ Category } & \multicolumn{2}{|c|}{ Animals } & \multicolumn{2}{|c|}{ Positives $^{1}$} & \multicolumn{2}{|c|}{ Positives $^{2}$} & \multirow{2}{*}{$\mathrm{P}$} \\
\hline & & $\mathrm{n}$ & $\%$ & $\mathrm{n}$ & $\%$ & $\mathrm{n}$ & $\%$ & \\
\hline \multirow{5}{*}{$\begin{array}{l}\text { Category } \\
\text { Group }\end{array}$} & Calf & 4 & 1.1 & 1 & 25.0 & 1 & 1 & \multirow[t]{5}{*}{0.985} \\
\hline & Heifer & 33 & 8.8 & 7 & 21.2 & 7 & 8 & \\
\hline & Lactating Cow & 314 & 84.2 & 72 & 22.9 & 72 & 84 & \\
\hline & Dry Cow & 19 & 5.1 & 5 & 26.3 & 5 & 6 & \\
\hline & Bull & 3 & 0.8 & 1 & 33.3 & 1 & 1 & \\
\hline \multirow[t]{8}{*}{ Breed } & Holstein & 164 & 44.0 & 38 & 23.2 & 38 & 44 & \multirow[t]{8}{*}{0.3207} \\
\hline & Jersey & 179 & 48.0 & 37 & 20.7 & 37 & 43 & \\
\hline & Flamenga & 5 & 1.3 & 1 & 20.0 & 1 & 1 & \\
\hline & Cross Breed & 7 & 1.9 & 4 & 57.1 & 4 & 5 & \\
\hline & Gir & 4 & 1.1 & 2 & 50.0 & 2 & 2 & \\
\hline & Mini-Jersey & 12 & 3.2 & 4 & 33.3 & 4 & 5 & \\
\hline & Lageano & 1 & 0.3 & 0 & 0.0 & 0 & 0 & \\
\hline & Norman & 1 & 0.3 & 0 & 0.0 & 0 & 0 & \\
\hline \multirow{4}{*}{$\begin{array}{l}\text { Milk } \\
\text { Production }\end{array}$} & High & 221 & 59.2 & 45 & 20.4 & 45 & 52 & \multirow[t]{4}{*}{0.008} \\
\hline & Middle & 73 & 19.6 & 17 & 23.3 & 17 & 20 & \\
\hline & Low & 18 & 4.8 & 10 & 55.6 & 10 & 12 & \\
\hline & No lactation & 61 & 16.4 & 14 & 23.0 & 14 & 16 & \\
\hline \multirow{6}{*}{$\begin{array}{l}\text { Reproductive } \\
\text { and Neurologic } \\
\text { Disorders }\end{array}$} & No Problems & 291 & 78.0 & 65 & 22.3 & 65 & 76 & \multirow[t]{6}{*}{0.528} \\
\hline & Abortions & 21 & 5.6 & 5 & 23.8 & 5 & 6 & \\
\hline & Return Season & 53 & 14.2 & 13 & 24.5 & 13 & 15 & \\
\hline & Stillborn & 6 & 1.6 & 2 & 33.3 & 2 & 2 & \\
\hline & Mummified & 1 & 0.3 & 1 & 100.0 & 1 & 1 & \\
\hline & Neurologic & 1 & 0.3 & 0 & 0.0 & 0 & 0 & \\
\hline Total & & 373 & 100 & 86 & - & 86 & 100 & \\
\hline
\end{tabular}

Positive $^{1}=$ Relation among the positive animals within a category and the total of animals of its category.

Positive $^{2}=$ Relation among the positive animals within a category and the total of positive animals.

$\mathrm{P}=$ descriptive level of the $\chi^{2}$ test.

Positives $^{1}=$ Relación entre los animales positivos dentro de la categoría y el número total de animales de su categoría

Positives $^{2}=$ Relación entre los animales positivos dentro de la categoría y el total de animales positivos.

$\mathrm{P}=$ Nivel descriptivo de la prueba $\chi^{2}$.

of $N$. caninum antibodies in cattle and Vega et al (2010) suggest that a close relationship between definitive and intermediate host, can facilitate the horizontal transmission. Interestingly, Barling et al (2001) suggested the presence of a dog among the cattle provided a protective factor against $N$. caninum infection. Perhaps the presence of a cattle-working dog prevented contamination of feed and water sources by other canids (stray and wild dogs) that might be more important sources of infection than tame dogs.
This study showed that $N$. caninum is present in dairy herds of Lages Municipality, Santa Catarina State with a prevalence of $23.1 \%$, which is within the range found in other important regions of cattle production in Brazil. Although age did not affect the presence of the protozoan $(P>0.05)$, the high percentage of positive cows suggest horizontal transmission of the agent inside the evaluated herds. The prevalence of antibodies against $N$. caninum was not associated with the existence of bovine reproductive disorders and the presence of dogs positive for $N$. caninum 
did not increase the risk factor for bovine neosporosis in the evaluated dairies.

\section{SUMMARY}

Bovines are the main intermediary host of the protozoan Neospora caninum, which is a major cause of bovine abortions and neonatal mortality worldwide. Sera were collected from 373 dairy cattle and 33 dogs on 19 dairy farms in Lages city, Santa Catarina State, Brazil, to determine the prevalence of $N$. caninum antibodies and risk factors. Tests for $N$. caninum antibodies were done using an indirect immunofluorescent antibody test (IFAT). Positive reactions with titers $\geq 1: 200$ (cattle) and $\geq 1: 50$ (dogs) were found in $86(23.1 \%)$ and seven $(21.2 \%)$ bovines and dogs, respectively. Of the bovines, four $(1.1 \%)$ were calves, $33(8.8 \%)$ were heifers, $314(84.2 \%)$ were lactating cows, $19(5.1 \%)$ were dry cows and three $(0.8 \%)$ were bulls. Infection was primarily found in animals with low milk production $(\mathrm{P}=0.008)$. The presence of seropositive dogs on the properties did not affect the prevalence of bovine infection. No correlation between bovine reproductive disorders and the prevalence of $N$. caninum antibodies was observed. Our results showed that $N$. caninum infection is widespread among dairy cattle of Lages, Santa Catarina.

\section{REFERENCES}

Aguiar DM, GT Cavalcante, AAR Rodrigues, MB Labruna, LMA Camargo, EP Camargo, SM Gennari. 2006. Prevalence of antiNeospora caninum antibodies in cattle and dogs from Western Amazon, Brazil, in association with some possible risk factors. Vet Parasitol 142, 71-77.

Almeida MAO. 2004. Epidemiology of Neospora caninum. Rev Bras Parasitol Vet 13, 38-40.

Almería S, F López-Gatius, I García-Ispierto, C Nogareda, G Bech-Sàbat, B Serrano, P Santolaria, JL Yániz. 2009. Effects of crossbreed pregnancies on the abortion risk of Neospora caninum-infected dairy cows Vet Parasitol 163, 323-329.

Baar BC, PA Conrad, KW Sverlow, AF Tarantal, AG Hendrickx. 1994. Experimental fetal and transplacental Neospora infection in the nonhuman primate. Lab Invest 71, 236-242.

Barling KS, JW Mcneill, JC Paschal, FT Mccollum Iii, TM Craig, LG Adams, JA Thompson. 2001. Ranch-management factors associated with antibody seropositivity for Neospora caninum in consignments of beef calves in Texas USA. Prev Vet Med 52, 53-61.

Basso W, S Schares, L Minke, A Barwald, A Maksimov, M Peters, C Schulze, M Muller, FJ Conraths, G Schares. 2010. Microsatellite typing and avidity analysis suggest a common source of infection in herds with epidemic Neospora caninum-associated bovine abortion. Vet Parasitol 173, 24-31.

Benetti AH, FB Schein, TR Santos, GH Toniollo, AJ Costa, JR Mineo, J Lobato, DAO Silva, SM Gennari. 2009. Inquiry of antibodies anti-Neospora caninum in dairy cattle, dogs and rural workers of the south-west region of Mato Grosso State. Rev Bras Parasitol Vet 18, 29-33. Supl 1.

Boaventura CM, VSF Oliveira, PPR Fernandes, GA Oliveira, AC Silva 2006. Ocorrência de anticorpos anti-Neospora caninum em bovinos do estado de Goiás In: CBPV (Ed). 14th Congresso Brasileiro de Parasitologia Veterinária, Ribeirao Preto, Brazil.

Conrad PA, BC Barr, KW Sverlow, M Anderson, B Daft, H Kinde, JP Dubey, L Munson, A Ardans. 1993. In vitro isolation and characterization of a Neospora sp from aborted bovine foetuses. Parasitology 106, 239-249.

Corbellini LG, D Driemeier, AM Mori, SD Traverso. 2001. Avaliação de um surto de aborto por Neospora caninum em uma propriedade leiteira do Estado de Santa Catarina Rev Bras Reprod Animal 25, 258-259.

Corbellini LG, DR Smith, CA Pescador, M Schmitz, A Correa, DJ Steffen, D Driemeier. 2006. Herd-level risk factors for Neospora caninum seroprevalence in dairy farms in southern Brazil. Prev Vet Med 74, 130-141.

Cruz CEF, DL Raymundo, C Cerva, SP Pavarini, AGC Dalto, LG Corbellini, D Driemeier. 2011. Records of performance and sanitary status from a dairy cattle herd in southern Brazil. Pesq Vet Bras 31, 1-9.

Davison HC, NP French, AJ Trees. 1999 ${ }^{\mathrm{a}}$. Herd-specific and age-specific seroprevalence of Neospora caninum in 14 British dairy herds. Vet Rec 144, 547-550.

Davison HC, A Otter, AJ Trees. 1999 ${ }^{\mathrm{b}}$. Significance of Neospora caninum in British dairy cattle determined by estimation of seroprevalence in normally calving cattle and aborting cattle. Int J Parasitol 29, 1189-1194.

De Meerschman F, N Speybroeck, D Berkvens, C Rettignera, C Focant, T Leclipteux, D Cassart, B Losson. 2002. Fetal infection with Neospora caninum in dairy and beef cattle in Belgium. Theriogenology 58, 933-945.

Dijkstra T, HW Barkema, C Björkman, W Andwouda. 2002. A high rate of seroconversion for Neospora caninum in a dairy herd without an obvious increased incidence of abortions. Vet Parasitol 109, 203-211.

Dubey JP, AL Hatel, DL Lindsay, MJ Topper. 1988. Neonatal Neospora caninum infection in dogs: Isolation of the causative agent and experimental transmission. $J$ Am Vet Med Assoc 193, 1259.

Dubey JP, DS Lindsay. 1996. A review of Neospora caninum and neosporosis. Vet Parasitol 67, 1-59.

Dubey JP, D Buxton, W Wouda. 2006. Pathogenesis of bovine neosporosis. J Comp Pathol 134, 267-289.

Dyer RM, MC Jenkins, OC Kwok, LW Douglas, JP Dubey. 2000. Serologic survey of Neospora caninum infection in a closed dairy cattle herd in Maryland: risk of serologic reactivity by production groups. Vet Parasitol 90, 171-181.

Flausino W, AD Munhoz, MJS Pereira, CWG Lopes. 2006. Dinâmica da infecção por Neospora caninum e a presença de abortos em bovinos leiteiros na mesorregião sul fluminense, estado do Rio de Janeiro. In: CBPV (ed). $14^{\text {th }}$ Congresso Brasileiro de Parasitologia Veterinária, Ribeirao Preto, Brazil.

Gennari SM. 2004. Neospora caninum no Brasil: Situação atual da pesquisa. Rev Bras Parasitol Vet 13, 23-27.

Ghalmi F, B China, B Losson. 2007. Diagnostic et surveillance epidemiologique de Neospora caninum. Ann Med Vet 151, 123-149.

Guedes MHP, AM Guimarães, CMBM Rocha, C Hirsch. 2008. Frequência de anticorpos anti-Neospora caninum em vacas e fetos provenientes de municípios do sul de Minas Gerais. Rev Bras Parasitol Vet 17, 189-194.

Guimarães Junior JS, SLP Souza, DP Bergamaschi, SM Gennari. 2004. Prevalence of Neospora caninum antibodies and factors associated with their presence in dairy cattle of the north of Paraná State, Brazil. Vet Parasitol 124, 1-8.

Guimarães AM, C Hirsch, GC Santana, MA Pereira, CMBM Rocha, MHP Guedes. 2006. Soroprevalência e fatores de risco para Neospora caninum em rebanhos leiteiros do sul de Minas Gerais. In: CBPV (Ed). 14th Congresso Brasileiro de Parasitologia Veterinária. Anais.

Hasegawa MY, IF Sartor, AMO Canavessi, RD Pinckney. 2004. Ocorrência de anticorpos anti-Neospora caninum em bovinos de corte e em cães da região de Avaré, Estado de São Paulo, Brasil. Semina 25, 45-50.

Hernandez J, C Risco, A Donovan. 2001. Association between exposure to Neospora caninum and milk production in dairy cows. J Am Vet Med Assoc 219, 632-635.

Hobson JC, TF Duffield, D Kelton, K Lissemore, SK Hietala, KE Leslie, B Mcewen, G Cramer, AS Peregrine. 2002. Neospora caninum serostatus and milk production of Holstein cattle. J Am Vet Med Assoc 221, 1160-1164.

Juliano RS, MCS Fioravanti, AC Silva, VSF Oliveira, PR Fernandes, CM Boaventura, ARB Silva, Souza, SN, GA Oliveira. 2006. Ocorrência de anticorpos anti-Neospora caninum e anti-Toxoplasma gondii 
em rebanhos da raça curraleiro. In: CBPV (ed). $14^{\text {th }}$ Congresso Brasileiro de Parasitologia Veterinária, Ribeirao Preto, Brazil.

Lobato J, DAO Silva, TWP Mineo, JDHF Amaral, GR Silva Segundo, JM Costa-Cruz, MS Ferreira, AS Borges, JR Mineo. 2006. Detection of immunoglobulin $\mathrm{G}$ antibodies to Neospora caninum in humans: High seropositivity rates in patients who are Infected by Human Immunodeficiency Virus or have neurological disorders. Clin Vaccine Immunol 13, 84-89.

Locatelli-Dittrich R, V Thomaz-Soccol, RRTB Richartz, ME GasinoJoineau, RVD Vinne, RD Pinckney. 2004. Isolamento de Neospora caninum de feto bovino de rebanho leiteiro no Paraná. Rev Bras Parasitol Vet 13, 103-109.

Locatelli-Dittrich R, PC Machado Jr, N Fridlund-Plugge, RRTB Richartz, F Montiani-Ferreira, LFL Patrício, MAC Patrício, MG Joineau, M Pieppe. 2008. Determinação e correlação de anticorpos antiNeospora caninum em bovinos e cães do Paraná, Brasil. Rev Bras Parasitol Vet 17, 191-196.

Mello RC, R Andreotti, JC Barros, RGP Tomich, AKM Mello, AI Campolim, AO Pellegrin. 2008. Levantamento epidemiológico de Neospora caninum em bovinos de assentamentos rurais em Corumbá, MS. Rev Bras Parasitol Vet 17, 311-316.

Melo CB, RC Leite, GN Souza, RC Leite. 2001. Freqüência de infecção por Neospora caninum em dois diferentes sistemas de produção de leite e fatores predisponentes à infecção em bovinos em Minas Gerais. Rev Bras Parasitol Vet 10, 67-74.

Melo DPG, AC Silva, LM Ortega-Mora, SA Bastos, CM Boaventura. 2006. Prevalência de anticorpos anti-Neospora caninum em bovinos das microrregiões de Goiânia e Anápolis, Goiás, Brasil. Rev Bras Parasitol Vet 15, 105-109.

Mineo TWP, S Alenius, K Näslund, HJ Montassier, C Björkman. 2006. Distribution of antibodies against Neospora caninum, BVBD and BHV-1 among cows in brazilian dairy herds with reproductive disorders. Rev Bras Parasitol Vet 15, 188-192.

Minervino AHH, AMA Ragozo, RM Monteiro, EL Ortolani, SM Gennari. 2008. Prevalence of Neospora caninum antibodies in cattle from Santarém, Pará, Brazil. Res Vet Sci 84, 254-256.

Munhoz AD, W Flausino, RT Silva, CRR Almeida, CWG Lopes. 2006. Distribuição de anticorpos conta Neospora caninum em vacas leiteiras dos municípios de Resende e Rio Claro, estado do Rio de Janeiro, Brasil. Rev Bras Parasitol Vet 15, 101-104.

Ogawa L, RL Freire, O Vidotto, LFP Gondin, IT Navarro. 2005. Occurrence of antibodies to Neospora caninum and Toxoplasma gondii in dairy cattle from the northern region of the Paraná State, Brazil. Arq Bras Med Vet Zootec 57, 312-316.

Oshiro LM, MFC Matos, JM Oliveira, LARC Monteiro, R Andreotti. 2007. Prevalence of anti-Neospora caninum antibodies in cattle from the State of Mato Grosso do Sul, Brazil. Rev Bras Parasitol Vet 16, 133-138.
Paré J, SK Hietala, MC Thurmond. 1995. Interpretation of an indirect fluorescent antibody test for diagnosis of Neospora sp infection in cattle. J Vet Diagn Invest 7, 273-275.

Paz GF, RC Leite, MA Rocha. 2007. Associação entre sorologia para Neospora caninum e taxa de prenhez em vacas receptoras de embriões. Arq Bras Med Vet Zootec 59, 1323-1325.

Ragozo AMA, VSO Paula, SLP Souza, DP Bergamaschi, SM Genari. 2003. Ocorrência de anticorpos anti-Neospora caninum em soros bovinos procedentes de seis estados brasileiros. Rev Bras Parasitol Vet 12, 33-37.

Rojo-Montejo S, E Collantes-Fernández, J Regidor-Cerrillo, G ÁlvarezGarcía, V Marugan-Hernández, S Pedraza-Díaz, J Blanco-Murcia, A Prenafeta, LM Ortega-Mora. 2009a. Isolation and characterization of a bovine isolate of Neospora caninum with low virulence. Vet Parasitol 159, 7-16.

Rojo-Montejo S, E Collantes-Fernandez, J Blanco-Murcia, A RodriguezBertos, V Risco-Castillo, LM Ortega-Mora. 2009 ${ }^{\mathrm{b}}$. Experimental infection with a low virulence isolate of Neospora caninum at 70 days gestation in cattle did not result in foetopathy. Vet Res 40, 40-49.

Romero-Salas D, Z Garcia-Vazquez, F Montiel-Palacios, T MontielPena, M Aguilar-Dominguez, L Medina-Esparza, C Cruz-Vazquez. 2010. Seroprevalence of Neospora caninum antibodies in cattle in Veracruz, México. J An Vet Adv 9, 1445-1451.

Sadrebazzaz A, G Habibi, H Haddadzadeh, J Ashrafi. 2007. Evaluation of bovine abortion associated with Neospora caninum by different diagnostic techniques in Mashhad, Iran. Parasitol Res 100, 1257-1260.

Silva DAO, J Lobato, TWP Mineo, JR Mineo. 2007. Evaluation of serological tests for the diagnosis of Neospora caninum infection in dogs: optimization of cut off titers and inhibition studies of crossreactivity with Toxoplasma gondii. Vet Parasitol 143, 234-244.

Thilsted JP, JP Dubey. 1989. Neosporosis-like abortions in a herd of dairy cattle. J Vet Diagn Invest 1, 205-209.

Thurmond MC, SK Hietala. 1997. Effect of Neospora caninum infection on milk production in first-lactation dairy cows. J Am Vet Med Assoc 210, 672-674.

Tiwari A, JA Vanleeuwen, IR Dohoo, GP Keefe, JP Haddad, R Tremblay, HM Scott, T Whiting. 2007. Production effects of pathogens causing bovine leukosis, bovine viral diarrhea, paratuberculosis, and neosporosis. J Dairy Sci 90, 659-669.

Vega OL, VA Chavez, PN Falcon, AE Casas, ChN Puray. 2010. Prevalence of Neospora caninum in shepherd dogs of a livestock farm in the southern highlands of Peru. Rev Investig Vet Peru 21, 80-86.

Vogel FSF, S Arenhart, FV Bauermann. 2006. Anticorpos anti-Neospora caninum em bovinos, ovinos e bubalinos no Estado do Rio Grande do Sul. Cienc Rural 36, 1948-1951.

Wang CR, Y Wang, X Zou, Y Zhai, J Gao, M Hou, X-Q Zhu. 2010. Seroprevalence of Neospora caninum infection in dairy cattle in northeastern China. J Parasitol 96, 451-452. 